\title{
Knowledge, Attitude and Practice of Insulin Use of Diabetic Patients in India
}

\author{
Venkataraman A P, Laxminarayana Kamath, Samhita Shankar
}

Department of Pharmacology,

Bangalore Medical College and Research Institute, Bangalore, Karnataka, India.

\begin{abstract}
Diabetes mellitus (DM) is a group of common metabolic disorders that share the phenotype of hyperglycemia. India is emerging as the world diabetic capital.Insulin is a therapeutic option to treat either type 1 and type $2 \mathrm{DM}$. Inadequate awareness about the use of insulin is likely to influence its acceptance and adherence. The present study was done to assess the knowledge, attitude, and practice regarding insulin use among diabetic patients at Victoria Hospital, Bangalore, India. Knowledge, attitude, and practice of sixty diabetic patients (either inpatients or outpatients) were assessed by using a validated questionnaire consisting of 24 items. Scores were allotted to each question and evaluated after applying appropriate statistical tests. The mean age of the patients was $53.51 \pm 6.48$ years $(58.33 \%$ males). The mean knowledge score was $9.06 \pm 1.88$ out of 22 , attitude score was $4.78 \pm 1.37$ out of 12 and practice score was $7.75 \pm 1.24$ out of 11 . The mean score of attitude was better in females compared to male patients $(5.32 \pm 1.34$ vs. $4.4 \pm 1.28)$. Male patients scored $38.57 \%$ compared to female patients $(41.33 \%)$ for question regarding symptoms of hypoglycemia. $57.14 \%$ of male patients and $72 \%$ of female patients carried simple carbohydrates when going out. Despite good practice score, the knowledge and attitude scores regarding insulin use were inadequate. Potential adverse effects of insulin can be avoided and better knowledge, attitude and practice can be achieved by providing proper education to patients.
\end{abstract}

Keywords : knowledge, attitude, practice, diabetic, insulin

\section{Introduction}

Diabetes mellitus (DM) is a group of common metabolic disorders that share the phenotype of hyperglycemia. ${ }^{1}$ Pathogenesis of DM is contributed by both genetic and environmental factors which involve insufficient insulin secretion, insulin resistance, increased glucose production and/or fat and protein metabolism abnormalities. ${ }^{2}$ Patients with diabetes are in a high risk of cardiovascular, peripheral vascular and cerebrovascular disease. $^{3,4}$ These complications can be prevented with appropriate and judicious medical care. ${ }^{5,6}$

India is emerging as the world diabetic capital. An estimated 72 million cases were reported in 2017 and expected to almost double by 2025. ${ }^{7}$ The prevalence of DM in Karnataka is $7.7 \%$ in $2017 .^{8}$ Type $1 \mathrm{DM}$ is the result of complete or near-total insulin deficiency. Type $2 \mathrm{DM}$ is a heterogeneous group of

Corresponding author: Venkataraman AP. Department of Pharmacology, Bangalore Medical College and Research Institute, Bengalore, Karnataka, India. Email: dr.apvr@gmail.com.

Received: 5 March 2020. Revised: 7 April 2020. Published: 21 April 2020. 
disorders characterized by variable degrees of insulin resistance, impaired insulin secretion, and increased glucose production. Type 2 diabetics frequently end up in need of insulin as the disease progresses. ${ }^{1}$ Thirty percent of all diabetic patients use insulin either alone or in combination with oral anti-diabetic drugs (OADs) in developed countries though this figure may be lower for India. ${ }^{9}$

Inadequate awareness regarding insulin use is likely to influence its acceptance $\&$ adherence. One third of patients fail to take their insulin as prescribed, and $20 \%$ of adults intentionally skip their doses. It's imperative that all the diabetic patients who use insulin should be educated about its use. ${ }^{10}$ Many studies have been published in India on diabetes epidemiology. However, knowledge, attitude and practice (KAP) survey of insulin use in diabetic patients is limited. Thus, the present study was conducted to assess the knowledge, attitude, and practice regarding insulin use among diabetic patients at Victoria Hospital, Banglore, India.

\section{Methods}

Study Population

This cross sectional, observational, KAP study was conducted in Bangalore Medical College and Research Institute, Department of Medicine. Inclusion criteria were patients: 1. Aged above 18 years old (both female and male)

2. Suffered type 1 and or type 2 DM under insulin therapy

3. Willing to participate in the study

Whereas, patients with extremes of age, pregnant, and lactating mother were excluded from the study.

\section{Data Collection}

The study was conducted from June 2018 to September 2018. The sample size was calculated using the previous studies. Prior to the enrollment, an informed consent was obtained from the patient in a language which they can best understand. A validated questionnaire was used to assess the KAP of any type of insulin use and its adverse effects. $^{15}$

The questionnaire contained 24 questions (8 questions for knowledge, 6 questions for attitude, and 10 questions of practice). The data collected through questionnaire were tabulated and evaluated. Results were analyzed based on categorization of the responses and expressed as percentage. All data were analyzed using Microsoft Excel software.

The responses were scored:

1. Yes: 1

2. No: 0

3. Partially: 0.5 (in attitude and practice), whereas each correct answer in knowledge was scored 1

The responses for the first 2 questions in the attitude were scored:

1. Strongly Agree: -2

2. Agree: -1

3. Unsure: 0

4. Disagree: +1

5.Strongly Disagree: +2

The score was reversed for the next 4 questions. Each correct answer in the practice was scored:

1.Yes: 1

2.No: 0

3. Sometimes/partial response: 0.5

The maximum and minimum scores were:

1. Knowledge: maximum 22, minimum 4

2. Attitude: ranged from -12 to +12

3. Practice: ranged from 2 to 11

The questionnaire used to evaluate the KAP of insulin use and its adverse effects are shown in Supplementary Table 1, Table 2 and Table 3 respectively. 


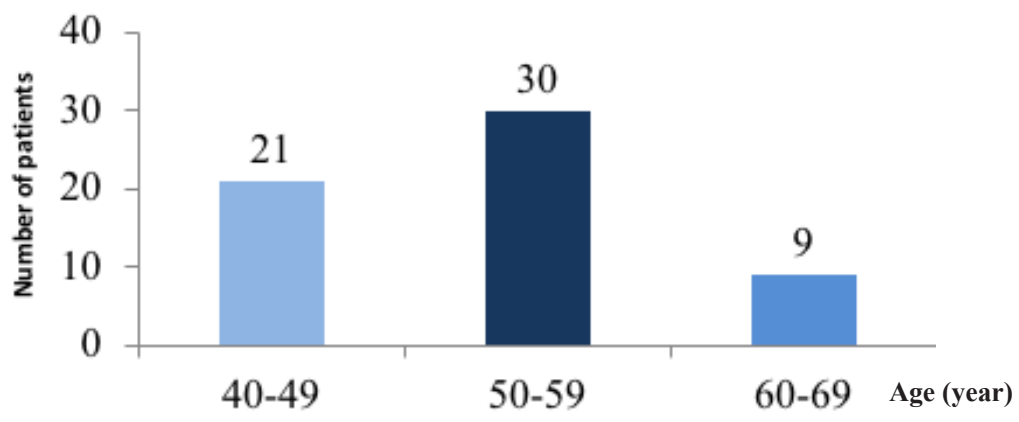

Figure 1. Age Distribution in the Study Population

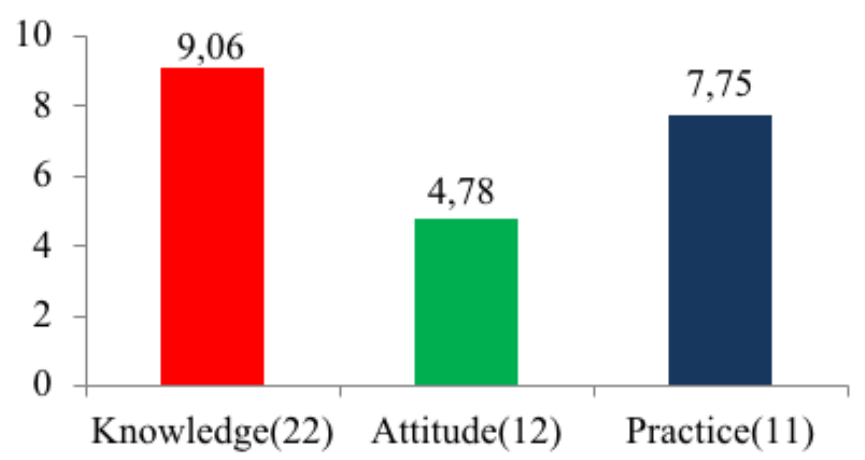

Figure 2. Mean of KAP Score

\section{Results and Discussion}

Diabetes continues to be a pandemic worldwide caused by a sedentary lifestyle and food habits. Genetic predisposition along with the fore mentioned factors have led to early onset of diabetes in the Indian population. ${ }^{11}$ Patients with diabetes needs to be continuously educated along with lifestyle modification, dietary adjustment, and insulin or oral-antidiabetic drug use, to prevent complications and adverse effects. The education is very essential in diabetics patients, especially for patients under insulin treatment. This KAP study was conducted to evaluate insulin use and its adverse effects.

KAP study was conducted in 60 diabetic patients based on inclusion and exclusion criteria ( 25 females and 35 males). In this study, we found the number of male patients was higher than females. The previous study showed that male patients are predominance in the prevalence of diabetes ${ }^{12}$ due to central obesity that more common in men. ${ }^{13}$ It shows that there are lifestyle differences between men and women in India, where men spend more time having meal outside. The mean age of the study population was 53.51 (6.48) years. A study in north India revealed that the prevalence of diabetes is higher in an age group ranging from 45 to 69 years, which is consistent with our study. ${ }^{14}$ The rising number of type 2 diabetic cases can be caused by urbanization and sedentary lifestyle.

Present study showed the mean scores of each parameter: knowledge was 9.06/22 (1.88), attitude score was 4.78/12 (1.37), and practice score was 7.75/11 (1.24). Our study showed a comparable knowledge score, whereas the attitude and practice score were better than in previous study that conducted in Tamil Nadu. ${ }^{15}$ This difference may be because of better health facility and its accessibility in Bangalore, India. 


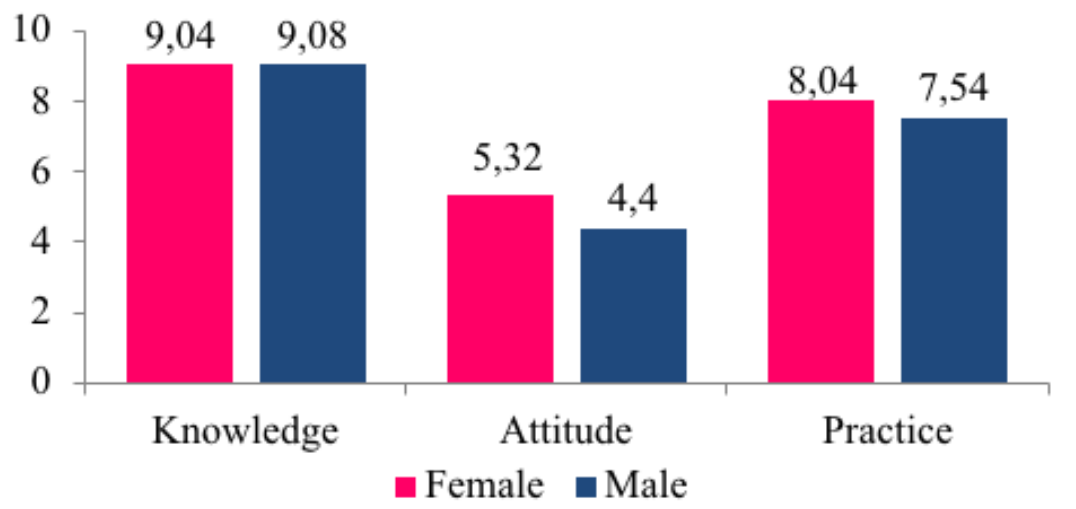

Figure 3. Mean KAP Score

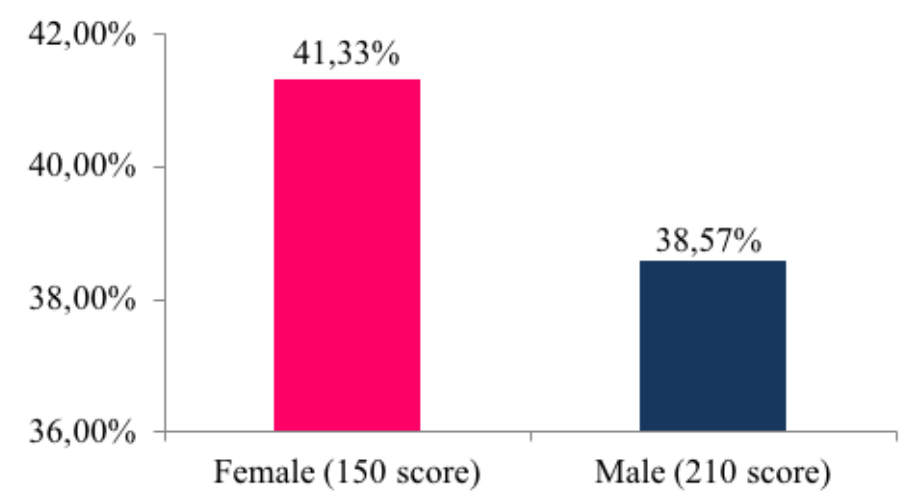

Figure 4. Percent of score: Awareness of the Symptoms of Hypoglycemia

The majority of the patients (90\%) know the action of insulin to reduce the glucose levels in the blood and this result was consistent with a study done by Jagadeesh et al in Andhra Pradesh, India. ${ }^{16}$ Only $33.3 \%$ of patients had knowledge about the signs and symptoms of diabetes, while other studies on Bhilai steel plant workers revealed $51 \%$ and $60-77 \%$ respectively. ${ }^{11,17}$ Hypoglycemia is one of complications on the treatment of diabetes. Almost $90 \%$ of patients who receive insulin have experienced hypoglycemic. ${ }^{18}$ Carrying simple sugars during a travel is important to prevent hypoglicemic. Previous studies showed $67.1 \%$ of patients prepared glucose $\mathrm{e}^{19}$, while others did not care about $(35.71 \%) .{ }^{20}$ Our study showed $63.3 \%$ of patients $(72 \%$ female and $57 \%$ male) carried some source of glucose all the time. This result stated that diabetes patients in Bangalore were aware of the possibility of hypoglycemia.

The major finding in our study was the lack of awareness about diabetes and sub-optimal KAP about insulin use and its adverse effects, which can be ascribed to many factors. The limitation of our study is a small study population. Since India is the diabetic capital of the world, so it's imperative to raise the awareness about diabetes and insulin use.

The integral part of comprehensive diabetes care is the information and education which leads to improvements in knowledge, attitude and practice. This can be achieved by many 


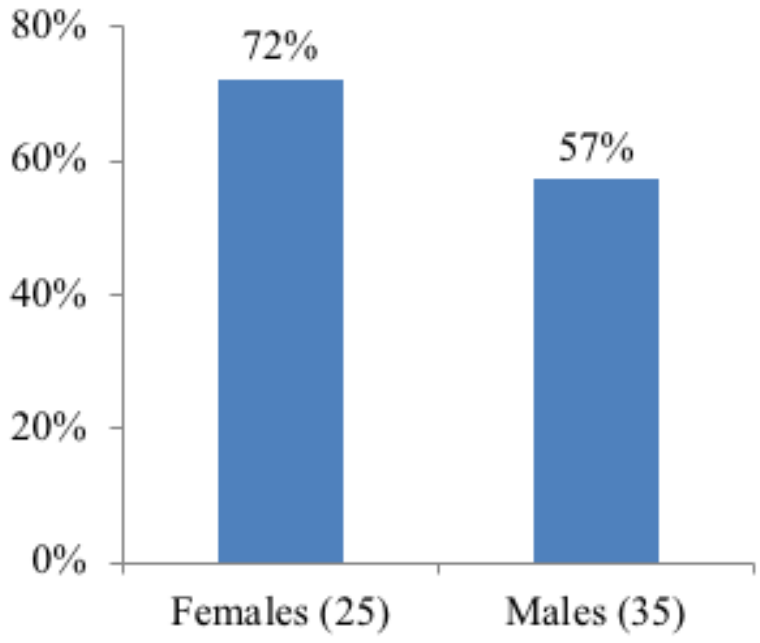

Figure 5. Percent of Patients Carried Glucose All the Time

ways like continuous audio and video display when the patients are waiting for consultation, A booklet with illustrations could be given to the patient that contains information on different types of insulin with their color code, sites of insulin administration, techniques of insulin administration, storage of insulin, signs of hypoglycemia and hyperglycemia, complications of insulin and its management. This might help the patients to have better understanding about self administration of insulin and also improve their practice skills.

Regular awareness programmes are also must to be held. The need of the hour is to have a separate course on diabetes in allied health sciences (AHS) which will provide surplus manpower to assist the diabetologist. All these measures will help to manage diabetes in an effective way.

\section{Conclusion}

This study showed that despite good practice score, the knowledge and attitude scores regarding insulin use were inadequate. The results are based on the patient's decisions which reflect about self-management of DM. All the diabetic patients should receive the much-needed education about the knowledge, attitude and practice of insulin use.

\section{Acknowledgment}

The authors would like to thank our colleagues and the faculty from the Department of Medicine, Bangalore Medical College and Research Institute, Bengaluru, for their immense support in conducting the project work.

\section{Funding}

None

\section{Conflict of interest}

None

\section{References}

1. Powers A C. Diabetes Mellitus: Diagnosis, Classification, and Pathophysiology. In: Lango D, Kasper DL, James Jl, Fausi AS, Hauser SL, Loscalzo J. editors. In: Harrison's principles of internal medicine. 19th Ed. New York: McGraw- Hill; 2012. p. 2399-435.

2. Powers A C, D'Alessio D. Endocrine Pancreas and Pharmacotherapy of Diabetes Mellitus and Hypoglycemia. In:Brunton LL, Chabner BA, Knollmann BC, editors. Goodman and Gilman's, The Pharmacological Basis of Therapeutics. 
12th Ed. New York: McGraw-Hill; 2011. p. 1237-271.

3. Alberti KG, Zimmet PZ. Definition, diagnosis and classification of diabetes mellitus and its complications. Part 1: diagnosis and classification of diabetes mellitus provisional report of a WHO consultation. Diabetic Medicine: A Journal of the British Diabetic Assosiation.1998;15(7):539-53.

4. UK Prospective Diabetes Study Group. Effect of intensive blood-glucose control with sulphonylureas or insulin compared with conventional treatment and risk of complications in patients with type 2 diabetes (UKPDS). Lancet 1998;35(2):837-53.

5. Colwell. J.A Tight blood pressure control andrisk ofmacrovascularandmicrovascular complications in type 2 diabetes: UK Prospective Diabetes Study Group. British Medical Journa1.1998;317:703-713.

6. Fuster. V.Robert.A. Orourke. R. Alexander. W Intensive blood-glucose control with sulphonylureas or insulin compared with conventional treatment and risk of complications in patients with type 2 diabetes UK Prospective Diabetes Study Group. Lancet. 1998;352:837-853.

7. Mohan V, Sandeep S, Deepa R, Shah B, Varghese C. Epidemiology of type 2 diabetes: Indian scenario. Indian Journal of Medical Research.2007;125:217-307.

8. Anjana RM, Deepa M, Pradeepa R, Mahanta J, Narain K, Das HK, et al. Prevalence of diabetes and prediabetes in 15 states of India: results from the ICMR-INDIAB population-based crosssectional study. The Lancet Diabetes \& Endocrinology [Internet]. 2017;5(8):58596. Available from: 10.1016/s22138587(17)30174-2.

9. United States Centers for Disease Control and Prevention. Diabetes data and trends: Age-adjusted percentage of adults with diabetes using diabetes medication, by type of medication, 2013. Available at: http://www.cdc.gov/diabetes/statistics/ meduse/fig2.htm.

10. Siminerio L, Kulkarni K, Pearson T, Rodbard H, Meece J, Lavernia F, et al. Strategies for Insulin InjectionTherapy in Diabetes Self-Management: American Association of Diabetes Educators.2011. Available from :http:// www.diabeteseducator.org/export/sites/ aade/_resources/pdf/research/AADE_Me Ed.pdf.

11. Behera SK, Behera RR, Thakur H. A study of knowledge and practices in prevention of type 2 diabetes mellitus among Bhilai steel plant employees. Indian Journal of Medical Specialities. 2012;3:143-8.

12. Anjana RM, Pradeepa R, Deepa M, Datta M, Sudha V, Unnikrishnan R, et al. Prevalence of diabetes and prediabetes (impaired fasting glucose and/or impaired glucose tolerance) in urban and rural India: Phase I results of the Indian Council of Medical ResearchINdiaDIABetes (ICMR-INDIAB) study. Diabetologia.2011;54:3022-27.

13. Nordström* A, Hadrévi J, Olsson T, Franks PW, Nordström P. Higher Prevalence of Type 2 Diabetes in Men Than in Women Is Associated With Differences in Visceral Fat Mass. The Journal of Clinical Endocrinology \& Metabolism .2016;101(10):3740-6.

14. Tripathy JP, Thakur JS, Gursimer J, Chawla S, Jain S, Arnab Pal, et al. Prevalence and risk factors of diabetes in a large community based study in North India: results from a STEPS survey in Punjab, India. Diabetol Metabolic Syndrome.2017;9(8):1-8.

15. Nivethitha T, Manickavasagam S, Paramasivam M, Thaejasvi SG. Knowledge, attitude and practice of insulin use and its adverse effects in adult diabetic population. International Journal of Basic 
Clinical Pharmacology.2017;6:2651-7.

16. JagadeeshA, RaviShankarK, Krishnakanth K. Study of knowledge concerning insulin usage in diabetic patients in tertiary care hospital in India. International Journal of Basic Clinical Pharmacology. 2018;7:5962.

17. Choudhary S D, Das S K, Hazra A. Survey of knowledge-attitude-practice concerning insulin use in adult diabetes patients in eastern India. Indian Journal of Pharmacology. 2014;46(4):425-429.

18. Shafiee G, Mohajeri-Tehrani M, Pajouhi M, Larijani B. The importance of hypoglycemia in diabetic patients. Journal of Diabetes \& Metabolic Disorders. 2012, 11:17

19. Priyanka Raj CK, Angadi MM. Hospitalbased KAP study on diabetes in Bijapur, Karnataka. Indian Journal of Medical Specialities. 2010;1:80-3.

20. Gawand K S, Gawali U P, Kesari H V. A Study To Assess Knowledge, Attitude And Practice Concerning Insulin Use In Adult Patients With Diabetes Mellitus In Tertiary Care Centre. Indian Journal of Medical Research and Pharmaceutical Sciences.2016;3(9). 
Supp Table 1. Knowledge of Insulin Use and its Adverse Effects

1. Please choose the correct statement

a) Diabetes is a disease characterized by low blood glucose and low insulin.

b) Diabetes is a disease characterized by high blood glucose and low insulin

c) Diabetes is a disease characterized by low blood glucose and high insulin

d) Diabetes is a disease characterized by high blood glucose and high insulin

2. Do you aware of various types of
a) Yes
b) No
c) Partially insulin?

3. Do you aware of the various insulin

a) Yes delivering devices?

b) No

c) Partially

4. Which of the following is/are the side

a) Low blood glucose effects of insulin therapy? (you can

b) Lipodystrophy tick more than one)

c) Allergy

d) Edema

5. Which of the following are the preferred sites injections of insulin? (you

a) Upper arm can tick more than one)

b) Thigh

c) Lower abdomen

d) Buttocks

6. How do you know the information about insulin? (you can tick more than

a) Books one)

b) Television

c) Internet

d) Physician/Doctor

7. Which of the following are the symptoms of the low blood glucose? (you

a) Sweating can tick more than one)

b) Rapid eartbeat

c) Tremors

d) Dizziness

e) Visual disturbances

f) Fatigue

8. Do you aware of $\mathrm{HbAlc}$ and the blood test check for long term control of

a) Yes blood glucose?

b) No

c) Partially 
Supp Table 2. Attitude of Insulin Use and its Adverse Effects

\begin{tabular}{|c|c|c|c|c|c|}
\hline Question & $\begin{array}{c}\text { Strongly } \\
\text { Agree }\end{array}$ & Agree & Unsure & Disagree & $\begin{array}{l}\text { Strongly } \\
\text { Disagree }\end{array}$ \\
\hline $\begin{array}{l}\text { 1. Once insulin is started, diet } \\
\text { and exercises are not needed }\end{array}$ & & & & & \\
\hline $\begin{array}{l}\text { 2. Insulin can be administered } \\
\text { even if the vial is having } \\
\text { clumps }\end{array}$ & & & & & \\
\hline $\begin{array}{l}\text { 3. Insulin can be stopped once } \\
\text { blood glucose is controlled }\end{array}$ & & & & & \\
\hline $\begin{array}{l}\text { 4. Insulin should not be adminis- } \\
\text { tered at the same site } \\
\end{array}$ & & & & & \\
\hline $\begin{array}{l}\text { Too high or too low insulin } \\
\text { can cause drastic alterations in } \\
\text { blood glucose }\end{array}$ & & & & & \\
\hline 6. I can self administer Insulin & & & & & \\
\hline
\end{tabular}


Supp Table 3. Practice of Insulin Use and its Adverse Effects

\begin{tabular}{|c|c|}
\hline 1. When do you inject insulin? & $\begin{array}{l}\text { a) } 20 \text { minutes before food } \\
\text { b) With food } \\
\text { c) } 20 \text { minutes after food } \\
\text { d) Anytime }\end{array}$ \\
\hline 2. How do you inject insulin? & $\begin{array}{l}\text { a) Retracting the injected surface, with needle } \\
\text { at } 45 \text { degree, subcutaneously } \\
\text { b) Retracting the injected surface, with needle } \\
\text { at } 90 \text { degree, subcutaneously } \\
\text { c) Retracting the injected surface, with needle } \\
\text { at } 45 \text { degree, intramuscularly } \\
\text { d) Retracting the injected surface, with needle } \\
\text { at } 90 \text { degree, intramuscularly }\end{array}$ \\
\hline $\begin{array}{l}\text { 3. Do you practice rotation of sites to } \\
\text { inject insulin? }\end{array}$ & $\begin{array}{l}\text { a) Yes } \\
\text { b) No }\end{array}$ \\
\hline $\begin{array}{l}\text { 4. Which of the following are the pre- } \\
\text { ferred sites injections of insulin? (you } \\
\text { can tick more than one) }\end{array}$ & $\begin{array}{l}\text { a) In refrigerator above freezing point } \\
\text { b) At room temperature } \\
\text { c) In refrigerator in freezing point } \\
\text { a) Anywhere }\end{array}$ \\
\hline $\begin{array}{l}\text { 5. Do you check for expiry date before } \\
\text { using insulin? }\end{array}$ & $\begin{array}{l}\text { a) Yes } \\
\text { b) No }\end{array}$ \\
\hline $\begin{array}{l}\text { 6. What will you do to the expired insu- } \\
\text { lin? }\end{array}$ & $\begin{array}{l}\text { a) Return it the local pharmacy } \\
\text { b) Will not take } \\
\text { c) Throw it in the dustbin } \\
\text { d) Will take }\end{array}$ \\
\hline $\begin{array}{l}\text { 7. Do you adhere to daily insulin injec- } \\
\text { tion? }\end{array}$ & $\begin{array}{l}\text { a) Yes } \\
\text { b) No }\end{array}$ \\
\hline $\begin{array}{l}\text { 8. If no, reasons for non-adherence to } \\
\text { daily insulin injections? }\end{array}$ & $\begin{array}{l}\text { a) Economic reasons } \\
\text { b) Fear of side effects or hypoglycemia } \\
\text { c) Disappearance of symptoms } \\
\text { d) Blood glucose controlled } \\
\text { e) Any other reason }\end{array}$ \\
\hline $\begin{array}{l}\text { 9. Do you keep a readily available source } \\
\text { of glucose when you go out? }\end{array}$ & $\begin{array}{l}\text { a) Yes } \\
\text { b) No }\end{array}$ \\
\hline $\begin{array}{l}\text { 10. How often do you check your blood } \\
\text { glucose and HbA1c? }\end{array}$ & $\begin{array}{l}\text { a) Once in } 3 \text { months } \\
\text { b) Once in } 6 \text { months } \\
\text { c) Once in } 9 \text { months } \\
\text { d) Annually }\end{array}$ \\
\hline
\end{tabular}

